DOI https://doi.org/10.30525/978-9934-26-005-6-3

\title{
ПРОБЛЕМИ ЗАБЕЗПЕЧЕННЯ НАЦІОНАЛЬНОЇ БЕЗПЕКИ У КОНТЕКСТІ ЗАБЕЗПЕЧЕННЯ СТІЙКОСТІ СОЦАЛЬНОГО ПОРЯДКУ
}

\author{
Ситник Г. П. \\ доктор наук з державного управління, професор, \\ заслужений діяч науки і техніки Украӥни, \\ професор кафедри державного управління \\ філософського факультету \\ Національного університету імені Тараса Шевченка \\ м. Київ, Україна
}

Ефективність соціального управління та консолідація суспільства навколо цілей, досягнення яких гарантує його безпеку, значною мірою залежить від вирішення проблеми забезпечення стійкості соціального порядку. При цьому сучасна епоха генерує все нові й нові виклики та невизначеності, які суттєво ускладнюють іï вирішення. Вирішенню проблеми забезпечення національної безпеки у контексті забезпечення стійкості соціального порядку, зокрема присвятили свої роботи дослідники [1-10]. Поміж іншого вони акцентують увагу, зокрема на: подвійній природі феномену безпеки людської спільноти, через що принципово важливим $\epsilon$ виокремлення безпеки в природній визначеності від безпеки людини, як свідомої істоти; ціннісних аспектах соціального порядку, а саме міксеризації ціннісних орієнтацій народів (націй) та маргіналізації носіїв культури під впливом масової культури; значних труднощах щодо забезпечення стійкості соціального порядку традиційними інструментами в епоху постмодерну, через що виникають кризові явища для державності та іiі компонентів; важливості наближення раціональних прагматичних цілей індивіду до інтересів та цілей розвитку суспільства та інститутів держави, як передумову забезпечення їх прогресивного та безпечного розвитку. 
Результати досліджень вказаних вчених розкривають сутність проблеми стійкості соціального порядку у контексті забезпечення національної безпеки та збереження життєвого потенціалу державності, як соціальної системи. Вказана стійкість акумулює результати зусиль суб'єктів публічного управління у сфері національної безпеки щодо реагування на небезпеки суспільно-політичній дестабілізації, територіальній цілісності, правам й свободам людини, руйнуванню культурноцивілізаційного коду народу. Тому забезпечення стійкості соціального порядку має бути пріоритетом у діяльності цих суб'єктів.

Люди (індивіди), значною мірою керуючись прагненням до безпеки, об'єднуються у групи та налагоджують між собою соціальні взаємодії, що мають на меті мінімізацію небезпеки їх життєдіяльності. Саме страх перед небезпеками, спонукає індивідів відмовлятися від свободи необмеженого самоствердження та об'єднуватися у суспільство. Інакше, як показав Т. Гоббс, вони можуть залишитися в стані, за якого ніхто не зможе їм гарантувати особисту недоторканність і безпеку [4]. При цьому безпека завжди $є$ соціальною цінністю для людей, оскільки створює умови для їх буття та розвитку, а знання про неї дають індивіду свободу вибору, розкривають його ціннісну значущість [5; 8]. Тому функція забезпечення безпеки є однією 3 найважливіших для державних інститутів та інституцій.

Значний внесок у розуміння соціального аспекту безпеки людини зробив Е. Дюркгейм, на думку якого визначальними

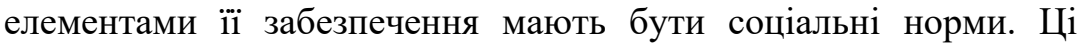
норми спрямовані на обмеження егоїстичних прагнення людини, запобігання соціальним конфліктам, їx врегулювання, a директивне регулювання іiї поведінки має здійснюватися шляхом формування у неї відповідних ціннісних орієнтацій [10]. Тому принцип цілісності систем зобов'язує забезпечувати соціальний порядок, сформований в інституційному середовищі, яке спонукає до об'єднання різноспрямованої діяльності іiї елементів у єдиний процес для досягнення загальних цілей, передусім щодо її безпеки. Таким чином, соціальний порядок, є цінністю 
для соціальної системи, оскільки його збереження забезпечує іiі існування як такої.

Дискусії щодо ефективних шляхів вирішення проблеми забезпечення стійкості соціального порядку, яка увійшла в історію наукової думки як Гоббсова проблема, не припиняються й до цього часу. Основна теза Т. Гоббса, полягає у тому, що вирішення цієї проблеми передбачає необхідність визначення домінуючого інституту (інстанції), здатного підтримувати стабільність суспільних відносин. На його думку, всі індивіди егоїсти. В умовах слабкості інститутів (правил) вони використовують для досягнення власної вигоди засоби, які можуть призвести до суспільно-політичної дестабілізації. Уникнути іiі дозволяє домінуюча інстанція шляхом агрегації індивідуальних некооперативних стратегій на макрорівні, що забезпечує колективний субоптимальний вибір, передусім у контексті забезпечення безпеки індивідів, суспільства та держави [4].

Запропоноване Т. Гоббсом рішення проблеми забезпечення стійкості соціального порядку лежить у політичній площині, що було актуальним у його епоху. Це рішення містить в собі дискурсивні елементи стосовно оптимізації балансу влади в трикутнику: індивід-суспільство-держава. Сучасна епоха, для якої характерним є кардинальне переосмислення та переоцінка ціннісних орієнтацій індивідів, актуалізує важливість врахування аксіологічного аспекту цієї проблеми. Це зумовлено труднощами держави максимізувати вигоди індивідів без інституційного примусу щодо дотримання правил, визначених у контексті системи національних цінностей, включаючи санкції щодо їх порушників. Тому найбільш гострі дискусії сьогодні пов'язані 3 оцінками сучасної місії та сенсу держави у контексті забезпечення соціального порядку. Крім того, сучасна епоха кидає виклик інституційній спроможності й інших інститутів за допомогою яких забезпечується соціальне управління, консолідація суспільства та безпека життєдіяльності індивідів, наприклад, політичним партіям, профспілкам тощо.

Загальновідомо, що задовольнити потреби людини (індивіду), суспільства та державних інститутів у безпеці спираючись тільки на моральні норми, які $\epsilon$ складовою 
національних цінностей, неможливо. Необхідно забезпечити захист цих цінностей нормами права шляхом їх включення у відповідні акти законодавства. Внаслідок цього система цінностей отримує офіційний статус й відповідний захист з боку держави. Так утворюються директивно-нормативні вимоги (правові норми) щодо поведінки кожного індивіда. При цьому, очевидно, що чим повніше ці норми враховують національні цінності, тим тісніший їх взаємозв'язок з моральними нормами, а відтак тим ефективніше вони виконують регулятивну функцію та впливають на свідомість та поведінку індивіда. У такому випадку вони, як, наприклад, й релігійні норми, культурні традиції, ставлення індивіда до своєї історичної спадщини визначають взірці та еталони його поведінки, тобто є потужним інструментом узгодження цілей індивідів та суспільства.

Проте правові норми, не можуть абсолютно точно відповідати ціннісним орієнтаціям індивіда та суспільства в цілому. Вони можуть по-різному усвідомлюватися й сприйматися людьми, які належать до різних соціальних груп, відповідати, або не відповідати їх потребам. Крім того, соціальні групи, в руках у яких зосереджена влада, можуть інтерпретувати свої інтереси як загальнонаціональні суспільні інтереси. Закріплюючи нормами права одні цінності, політичні інститути часто нівелюють інші, які не відповідають їх уявленням про ідеальний соціальний порядок та пріоритети державного будівництва. Тому інтереси людини (індивіда) та суспільства в цілому можуть не співпадати 3 проголошеними інтересами державної бюрократії. Внаслідок цього виникають суперечності між їх цілями щодо шляхів, засобів й способів забезпечення стійкості соціального порядку та національної безпеки.

Таким чином, правові норми мають бути адекватними завданням щодо забезпечення вказаної стійкості та національної безпеки, щоб мінімізувати негативні наслідки боротьби соціальних груп, які можуть мати різні ціннісні пріоритети.

Традиційні цінності в суспільстві $\epsilon$ результатом суперництва та компромісу між цінностями та ціннісними орієнтаціями індивідів та соціальних груп. Тому головною причиною небезпек стійкості соціальному порядку, які 20 
призводить до дезінтеграції суспільства $є$ невідповідність цих цінностей ідеологічним засадам, програмним цілям та правовим нормам щодо розвитку суспільства та держави, які визначаються вищим політичним керівництвом.

\section{Література:}

1. Бек У. Власть и ее оппоненты в эпоху глобализма. Новая всемирно-политическая экономия / пер. с нем. А.Б.Григорьева, В.Д. Седельника; послесл. В.Г. Федотовой, Н.Н. Федотовой. Москва: Прогресс-Традиция; Издательский дом «Территория будущего», 2007. 464 с.

2. Бодрийяр Ж. Общество потребления. М. : Республика, Культурная революция, 2006.

3. Курин С.Я., Воробьев В.П. Болезни государства. Диагностика политической системы государственного управления и права: монографія. Москва: МГИМО (У) МИД России. 2009. 472 с.

4. Гоббс Т. Левіафан, або Матерія, форма і влада держави церковного і цивільного. твори: У 2 т. Т. 2 . Москва: Думка, $1991.736 \mathrm{c}$.

5. Горбулін В. П., Качинський А. Б. Стратегічне планування: вирішення проблем національної безпеки : монографія. Київ: НІСД, 2010. 288 с.

6. Маньков В. Д. Безопасность общества и человека в современном мире: монографія. СПб.: Политехника, 2005. 551 с.

7. Орел М. Г. Теоретичні основи державного управління у сфері політичної безпеки: монографія. Київ: «Поліграф Плюс», 2019. $320 \mathrm{c}$.

8. Ситник Г.П. Державне управління національною безпекою України (теорія і практика): монографія. Київ: НАДУ, 2004. 408 c.

9. Станкевич А.А. Устойчивое развитие систем: от концепции к социальной устойчивости. Науч.весник «Финансы, банки, инвестиции». 2018. № 2. С. 174-180.

10. Дюркгейм Э. Социология. Ее предмет, метод, предназначение / пер. с фр., сост., послесл. и прим. А.Б.Гофмана. Москва: Канон, 1995. 352 с. 